Giur Hargiana \& Tia Sintiawati

Hubungan Ketergantungan Gawai dengan Stres Akademik Pada Mahasiswa Keperawatan

\title{
Hubungan Ketergantungan Gawai Dengan Stres Akademik Pada Mahasiswa Keperawatan
}

\author{
Giur Hargiana ${ }^{1}$, Tia Sintiawati ${ }^{2}$ \\ ${ }^{1)}$ Departemen Keperawatan Jiwa Fakultas Ilmu Keperawatan, Universitas Indonesia \\ ${ }^{2)}$ Program Studi Sarjana Fakultas Ilmu Keperawatan, Universitas Indonesia
}

Korespondensi penulis: giurhargiana@ui.ac.id

\begin{abstract}
Abstrak
Pada perkembangan era digital saat ini istilah kecanduan sudah memiliki perkembangan yang sangat dinamis, bukan hanya kecanduan narkoba namun kecanduan gawai merupakan bentuk kecanduan yang berbahaya dan memiliki efek yang luas dimasyarakat. Generasi Z, merupakan populasi usia dewasa muda saat ini, generasi ini berkembang di era digital, sehingga pembentukan kopingnya pun terpengaruh oleh hal tersebut. Pada usia dewasa muda, biasanya orang sedang dalam fase pendidikan tinggi sebagai mahasiswa, mahasiswa disibukkan oleh berbagai kesibukan baik akademik maupun non akademik. Hal ini membuat mahasiswa rentan mengalami stres. Salah satu stresor yang mahasiswa rasakan selama perkuliahannya yaitu berkaitan dengan stres akademik. Penelitian ini bertujuan untuk mengidentifikasi gambaran tingkat ketergantungan gawai dan tingkat stres akademik pada mahasiswa di FIK UI dan untuk mencari hubungan keduanya menggunakan kuesioner Academic Stress Scale (ASS) dan Test for Gadget Dependency. Desain penelitian ini adalah cross sectional, teknik sampel menggunakan proportional stratified random sampling dengan melibatkan 229 mahasiswa. Hasil analisis uji statistik chi-square didapatkan $p=$ 0,000 dan nilai $p<a=0,05$ yang berarti terdapat hubungan yang signifikan antara ketergantungan terhadap gawai dengan stres akademik pada mahasiswa. Hasil penelitian ini juga menemukan mahasiswa mengalami stres akademik sedang sebanyak 66,4\% dan mahasiswa mengalami ketergantungan terhadap gawai pada kategori sedang sebanyak 69,9\%. Ketergantungan terhadap gawai dan stress akademik memiliki hubungan yang saling memengaruhi, seseorang dengan ketergantungan gawai yang tinggi akan memiliki stress akademik yang tinggi pula dan sebaliknya. Rekomendasi dari penelitian ini mahasiswa perlu aware dengan perilaku dalam menggunakan gawai.
\end{abstract}

Kata kunci: ketergantungan gawai; mahasiswa keperawatan; stres akademik

\section{PENDAHULUAN}

Gawai sudah menjadi bagian dari kehidupan manusia yang tidak terpisahkan dewasa ini. Pertumbuhan pengguan gawai telah meningkat secara eksponensial dalam decade ini. Saat ini hampir semua orang sudah memiliki dengan satu atau lebih gawai (Hegde, et.al 2018). Peran gawai dalam kehidupan sehari-hari semakin berkembang, di era sekarang, dengan diperkenalkannya berbagai teknologi modern pada gawai, ketergantungan orang pada teknologi dan layanan yang disediakan oleh gawai telah mencapai pada tingkatan tersendiri. Hal tersebut menyebabkan muncul ungkapan tanpa gawai, kemajuan dalam kehidupan tampaknya mustahil. Generasi Z, yaitu generasi sekarang yang memiliki keterikatan secara psikologis pada gawai, walaupun tujuan penggunaan gawai tersebut dalam banyak kasus lebih karena "dorongan kesenangan" dibandingkan dengan "dorongan kebutuhan" (Revathi, et.al 2020). 
Giur Hargiana \& Tia Sintiawati

Hubungan Ketergantungan Gawai dengan Stres Akademik Pada Mahasiswa Keperawatan

Penggunaan gawai pada generasi $\mathrm{Z}$ yang pada saat ini berada pada tahapan usia remaja-dewasa muda, salah satunya mereka berstatus dan berperan sebagai mahasiswa. Dalam kesehariaanya mahasiswa menggunakan gawai untuk memenuhi berbagai macam keperluan. Ketergantungan terhadap gawai yang dialami oleh generasi muda menunjukan tingkat yang memprihatinkan, Sebagian besar generasi muda mengalami ketergantungan terhadap gawai mengalami masalah terhadap kesehatan secara umum maupun bagi hubungan sosial mereka (Revathi, et.al 2020, Kumar, et.al 2018).

Mahasiswa pada berbagai bidang studi memiliki stressornya masingmasing, namun pada penelitian ini akan berfokus pada mahasiswa keperawatan. Dasarnya adalah hasil penelitian menunjukan prevalensi mahasiswa dengan tingkat stres tinggi sebagian besar dialami oleh mahasiswa kesehatan yaitu sebesar $57,4 \%$ yang terdiri dari mahasiswa keperawatan sebesar 63,3\%, kedokteran sebesar $57 \%$ dan kedokteran gigi sebesar 50\% (Amanya, Nakitende, \& Ngabirano, 2017). Dari penelitian tersebut dapat dilihat bahwa mahasiswa keperawatan memiliki tingkat stress yang relative lebih tinggi.

Berdasarkan studi menunjukkan bahwa mahasiswa keperawatan memiliki tingkat stres yang lebih tinggi dan rentan dibandingkan dengan mahasiswa kesehatan lainnya (Papazisis, Tsiga, Papanikolaou, \& Vlasiadis, 2008; Labrague, 2013; Labrague, Mcenroe, Alexis, Santos, \& Edet, 2018). Salah satu faktor risiko stres paling dominan pada mahasiswa adalah stres akademik (Waghachavare, Dhumale, Kadam, \& Gore, 2013; Okoro, 2018). Penelitian yang teridentifikasi pada mahasiswa $\mathrm{S} 1$ reguler FIK UI, terdapat mahasiswa yang memiliki $151(66,5 \%)$ responden yang mengalami tingkat stres akademik rendah dan sebanyak 44,9\% mengalami tingkat stres akademik tinggi (Afifah, 2018). Stres yang dialami mahasiswa keperawatan ini dapat ditimbulkan oleh berbagai stresor.

\section{METODE}

Desain penelitian yang digunakan dalam penelitian ini adalah studi cross sectional dengan populasi mahasiswa Reguler Fakultas Keperawatan Universitas Indonesia berjumlah 453 orang mahasiswa berstatus aktif. Pengambilan sampelnya menggunakan teknik proportional stratified random sampling dengan sampel 229 responden.

Instrumen yang digunakan untuk stres akademik yaitu kuesioner Academic Stress Scale (ASS) yang dikembangkan oleh Rao (2013) yang terdiri 40 pertanyaan dengan skala likert. Instrumen telah dilakukan uji validitas dan reliabilitas oleh Awaludin (2015), hasilnya pertanyaan valid $(0,361-0,603)$ dan reliabel $(\mathrm{r}=0,963)$. Sedangkan instrumen ketergantungan pada gawai yaitu Test for Gadget Dependency yang dikembangkan oleh Kumar, Aravind \& Sherkhane, Mayur, 2018) terdiri dari 10 pertanyaan dan menggunakan skala likert, hasil uji validates reliabilitas valid $(0,383-0,707)$ dan reliabel $(r=0,973)$.

\section{HASIL}

\section{Karakteristik responden}

Hasil penelitian ini mengenai karakteristik responden didapatkan rerata usia responden 20 tahun dengan rentang usia 18-23 tahun sehingga dapat disimpulkan bahwa usia 
Giur Hargiana \& Tia Sintiawati

Hubungan Ketergantungan Gawai dengan Stres Akademik Pada Mahasiswa Keperawatan

mahasiswa program regular FIK UI berada pada tahap perkembangan remaja akhir sampai dewasa awal. Responden juga didominasi perempuan dibandingkan laki-laki yaitu sebanyak 216 orang $(94,3 \%)$.
Mayoritas indeks prestasi (IP) semester terakhir mahasiswa yang menjadi responden yaitu $(2,76-3,50)$ berjumlah 155 orang $(67,7 \%)$ mahasiswa sehingga dikategorikan dengan indeks prestasi kategori baik.

Tabel 1. Gambaran Tingkat Stres Akademik $(\mathbf{n}=\mathbf{2 2 9})$

\begin{tabular}{ccc}
\hline Tingkat Stres Akademik & Frekuensi & Persentase (\%) \\
\hline Rendah & 43 & 18,8 \\
\hline Sedang & 152 & 66,4 \\
\hline Tinggi & 34 & 14,8 \\
\hline
\end{tabular}

Mahasiswa S1 Reguler Fakultas Ilmu Keperawatan Universitas Indonesia (FIK UI) paling banyak memiliki tingkat stres akademik sedang sebanyak 152 orang $(66,4 \%)$. Sedangkan sebanyak 43 orang $(18,8 \%)$ mengalami tingkat stres akademik rendah dan 34 orang $(14,8 \%)$ mengalami tingkat stres akademik tinggi.

Tabel 2. Gambaran Ketergantungan Gawai $(\mathbf{n}=\mathbf{2 2 9}$

\begin{tabular}{ccc}
\hline Kecanduan Gawai & Frekuensi & Persentase $(\%)$ \\
\hline Rendah & 32 & 13,9 \\
\hline Sedang & 160 & 69,9 \\
\hline Tinggi & 37 & 16,2
\end{tabular}

Terdapat 32 orang $(13,9 \%)$ responden mengalami ketergantungan gawai rendah, 160 orang $(69,9 \%)$ responden mengalami ketergantungan gawai sedang dan 37 orang $(16,2,1 \%)$ mengalami ketergantungan gawai tinggi.

Tabel 3. Hubungan Antara Ketergantungan Gawai Dan Tingkat Stress Akademik $(\mathbf{n}=\mathbf{2 2 9})$

\begin{tabular}{cccccc}
\hline Stress Akademik & \multicolumn{5}{c}{ Ketergantungan Gawai } \\
\cline { 2 - 5 } & Rendah & Sedang & Tinggi & Total & $p$ \\
Rendah & 22 & 18 & 3 & 43 & \\
Sedang & 8 & 134 & 10 & 152 & \\
\cline { 1 - 5 } 0 & 2 & 8 & 24 & 34 & \\
\hline Tinggi & 32 & 160 & 37 & 229 & \\
\hline Total & & & &
\end{tabular}

Tabel 3 menunjukkan bahwa ada 134 mahasiswa (58,5\%) mengalami tingkat stres sedang dengan tingkat ketergantungan sedang, Berdasarkan hasil analisis uji statistik chi-square didapatkan nilai $\mathrm{p}=0,000$ dan nilai $\mathrm{p}<\mathrm{a}=0,05$. Hasil tersebut menunjukkan bahwa terdapat hubungan yang signifikan antara ketergantungan gawai dan stres akademik.

\section{PEMBAHASAN}

\section{Tingkat Stres Akademik}

Data hasil penelitian

menunjukan sebanyak $66,4 \%$ mahasiswa mengalami stress akademik dengan kriteria sedang. Hal ini sejalan dengan penelitian yang dilakukan oleh Psychology Foundation of Australia (2010) 
Giur Hargiana \& Tia Sintiawati

Hubungan Ketergantungan Gawai dengan Stres Akademik Pada Mahasiswa Keperawatan

individu yang mengalami stres akademik sedang cenderung mudah emosi dan tidak fokus sehingga mempengaruhi kemampuan dan orientasi terhadap kegiatan proses pembelajaran yang diikuti oleh mahasiswa. Hasilnya mahasiswa menjadi pusing, penundaan dalam penyelesaian tugas dan mengalami gangguan tidur.

Hasil penelitian lainnya melaporkan mahasiswa keperawatan mengalami gangguan dari teman, guru dan juga takut melihat darah, suntikan, operasi, adanya kasus kecelakaan selama pelatihan menjadi factor stress yang berpengaruh terhadap tingkat stress akademik mahasiswa keperawatan (Jirel, sharma, Dawadi, 2018). Hasil penelitian ini sejalan dengan penelitian yang disebutkan diatas, bahwa stress akademik khas di mahasiswa keperawatan ada hubungannya dengan proses pembelajaran yang dilakukan.

Stres akademik pada mahasiswa keperawatan biasanya muncul sebagai gejala gangguan psikososial umum (Common mental distress). Masalah ini berhubungan dengan beberapa hal yang membuat frustrasi yang terkait dengan kegagalan akademik seperti tekanan-tekanan dan ketegangan saat menghadapi ujian, beban tugas yang tinggi dan tantangan tersendiri yang dihadapi pada saat praktik klinik (Jirel, sharma, Dawadi, 2018). Hasil penelitian tersebut mewakili hampir semua mahasiswa keperawatan, karena dalam keperawatan stress akademik yang muncul bukan hanya dari proses pembelajaran di kelas namun juga di tatanan klinis.

Pengaturan waktu yang kurang baik ditambah dengan kebiasaan menunda-nunda dalam pengerjaan tugas kuliah yang diberikan merupakan penyebab stress akademik yang umumnya dialami oleh mahasiswa keperawatan dalam menjalani perkuliahannya. Pengaturan dan pengguanaan waktu yang baik dapat mereduksi stress akademik yang terjadi pada mahasiswa keperawatan. Dampak dari stress akademik yang disebabkan oleh berbagai macam faktor yang terjadi dipengaruhi juga oleh mekanisme koping yang dimiliki oleh mahasiswa keperawatan itu sendiri. Jika mekanisme koping yang digunakan adalah menghindar maka akan dapat memperparah kondisi stress akademiknya dan pada akhirnya akan berpengaruh pada performa akademik yang menyebabkan performa dan hasil menjadi kurang baik (Nayak, Shalini G, 2019). Untuk mengatasi dampak pada performa akademik maka perlu disadari oleh mahasiswa keperawatan dalam menjalani perkuliahan.

\section{Ketergantungan Gawai}

Teknologi telah menjadi bagian yang meluas dan tak terpisahkan dari kehidupan kita selama beberapa dekade terakhir. Banyak peneliti telah meneliti dampak teknologi terhadap manusia sebagai individu, keluarga, kelompok maupun masyarakat. Gawai dengan berbagai macam perkembangan teknologi pada bentuk dan fungsinya telah berkembang menjadi bagian tak terpisahkan dari kehidupan kita sehari-hari. Peningkatan jumlah orang dewasa yang memiliki perangkat media digital meningkat lebih dari dua kali lipat. Sebagai contoh, pada tahun 2000, hanya $53 \%$ orang dewasa yang memiliki ponsel, tetapi jumlah ini meningkat menjadi $92 \%$ pada tahun 2015. Selanjutnya, kepemilikan ponsel cerdas orang dewasa meningkat dari $35 \%$ pada tahun 2011, menjadi $68 \%$ pada tahun 2015 (Smith, 2015). 
Giur Hargiana \& Tia Sintiawati

Hubungan Ketergantungan Gawai dengan Stres Akademik Pada Mahasiswa Keperawatan

Namun demikian masih banyak sekali orang yang belum menyadari secara mendasar peran dan fungsi gawai yang sangat dapat membawa kebermanfaatan yang luas (Andreassen \& Pallesen, dalam Moris and Picken 2017). Data hasil penelitian menunjukan angka ketergantungan terhadap gawai sedang sebanyak $69,9 \%$ dan ketergantungan tinggi sebanyak 16,2\%. Muncul pertanyaan yang perlu didiskusikan yaitu orang yang memiliki angka ketergantungan sedang dan tinggi tersebut menggunakan gawai sebagai dorongan kebutuhan atau ada dorongan lainnya untuk bermain game. Hussain et al (2011) mengungkapkan bahwa kegiatan bermain game didominasi oleh orang dengan rentang usia remaja dan dewasa muda, sejumlah $44,5 \%$ pemain game tersebut terklasifikasi sebagai orang yang kecanduan terhadap game.

Dew \& Tulane (2015) mengungkapkan hasil penelitian bahwa hampir seluruh orang yang menggunakan gawai pasti pernah menggunakan gawainya tersebut untuk mendapatkan hiburan yang menyenangkan bagi dirinya. Selain untuk kepentingan hiburan, penggunaan gadget dikalangan mahasiswa juga dimanfaatkan untuk akses terhadap berbagai macam proses pembelajaran, dimulai dari pencarian sumber pembejaran sampai dengan sebagai media pembelajaran itu sendiri (Domingo\&Gargante, 2016).

Pemanfaatan gawai dewasa ini juga sudah digunakan secara luas untuk mempermudah proses penelitian yang dilakukan oleh mahasiswa (Tsatsou, 2016). Penggunaan gawai merupakan hal yang tidak terpisahkan dan tidak dapat terelakan dalam kehidupan sehari-hari saat ini, namun penggunaan tersebut dapat menjadi dua sisi mata uang yang saling bertolak belakang secara fungsionalitas, bagaimana mahasiswa mengelola diri untuk dapat memanfaatkan gawai sebagai alat untuk menunjang produktifitas bukan sebaliknya.

\section{Hubungan Ketergantungan Gawai dengan Stres Akademik}

Ketergantungan gawai dan stress akademik pada mahasiswa keperawatan memiliki hubungan yang signifikan dengan arah positif. Itu artinya semakin tinggi ketergantugan gawai maka akan semakin tinggi juga tingkat stress akademik yang dialami oleh mahasiswa keperawatan. Hasil menunjukan sebagian besar mahasiswa keperawatan memiliki tingkat ketergantungan terhadap gawai dan stress akademik dalam kategori sedang. Tingkat ini mempengaruhi memori, konsentrasi dan kemampuan pemecahan masalah, mengarah pada penurunan pembelajaran, koping, dan kinerja akademik (Goff, 2011).

Hal ini kosisten dengan penelitian yang menunjukkan beberapa orang cenderung bergantung pada gawai untuk mengurangi stresnya (Jirel, 2019). Salah satu penggunaan gawai yang paling besar adalah akses internet, ditemukan hubungan positif yang kuat antara stres dan risiko kecanduan internet (Gupta, Khan, Rajoura dan Srivastava, 2018), terlalu lama dalam mengakses internet untuk kepentingan hiburan membuat mahasiswa kurang baik dalam pengaturan waktu untuk mengerjakan hal lain yang lebih penting.

Hubungan antara ketergantungan gawai dan stress akademik dapat saling memengaruhi satu sama lain, ketergantungan gawai dapat menyebabkan peningkatan stress akademik karena dengan 
Giur Hargiana \& Tia Sintiawati

Hubungan Ketergantungan Gawai dengan Stres Akademik Pada Mahasiswa Keperawatan

ketergantungan gawai waktu yang dimiliki oleh mahasiswa tersita dengan penggunaan gawainya. Stress akademik pun dapat berpengaruh terhadap ketergantungan gawai, hal ini dapat terjadi karena saat mahasiswa mendapati stressor mekanisme koping yang digunakan oleh mahasiswa yang notabene adalah generasi $\mathrm{Z}$, adalah penggunaan gawai untuk tujuan mencari hiburan. Bentuk hiburan yang dimaksud meliputi bermain game, mengakses media sosial secara berlebihan dan melakukan surfing di internet tanpa tujuan yang terarah dengan baik (Eilish and Duke, 2017)

\section{KESIMPULAN}

Tingginya angka pengguanaan gawai oleh mahasiswa saat ini sudah merupakan cerminan dari kebutuhan yang dapat dipenuhi oleh gawai dan teknologi yang terdapat didalamnya. Fenomena menarik yang didapat dari hasil penelitian adalah Sebagian besar responden penelitian mengalami tingkat ketergantungan pada gawai sedang, hal ini mengindikasikan penggunaan gadget bukan hanya untuk tujuan produktif saja namun juga untuk hiburan yang mengarah pada penggunaan yang hanya memenuhi keinginan saja tidak berbasis pada kebutuhan.

Mahasiswa keperawatan pada hasil penelitian ini Sebagian besar memiliki tingkat stress akademik yang sedang, stress akademik ini untuk mengatasinya dapat menggunakan berbagai mekanisme koping, jika mekanisme koping yang digunakan adalah menghindar maka dampak stress akademik akan semakin memburuk. Salah satu bentuk menghindar dari stressor akademik adalah dengan menggunakan gawai secara berlebihan, menggunakan gawai bukan dengan tujuan untuk memenuhi kebutuhan untuk menghasilkan sesuatu yang produsktif, namun lebih untuk menghidar dan mencar kesenangan melalui hiburan.

Stress akademik dan ketergantungan gawai menjadi dua variabel yang dapat saling memengaruhi satu dengan lainnya. Bagi mahasiswa keperawatan akan baik bagi perkembangan personal terutama untuk mengurangi stress akademik jika mahasiswa menyadari terkait dengan apa yang membuat stress secara akademik dan mencari penanganan yang terbaik. Gawai sebaiknya dapat digunakan sebagai alat untuk mencapai tujuan yang produktif, bahkan untuk mengurangi stress namun bukan dengan bentuk koping menghindar seperti mencari hiburan sesaat, namun mencari penyelesaian terhadap stressor yang muncul pada kehidupan akademik. Diharapkan juga institusi pendidikan keperawatan dapat memaksimalkan peran fungsi assessment mengenai kondisi stress akademik mahasiswa agar dapat digunakan untuk meningkatkan prestasi mahasiswa maupun institusi.

\section{DAFTAR PUSTAKA}

Afifah. (2018). Hubungan Stres Akademik dengan Gejala Gastrointestinal pada Mahasiswa Fakultas Ilmu Keperawatan Universitas Indonesia. Depok: Universitas Indonesia.

Amanya, S. B., Nakitende, J., \& Ngabirano, T. D. (2017). RESEARCH ARTICLE A cross- sectional study of stress and its sources among health professional students at Makerere University , Uganda, (October 2017), 70-76. https://doi.org/10.1002/nop2.113 
Giur Hargiana \& Tia Sintiawati

Hubungan Ketergantungan Gawai dengan Stres Akademik Pada Mahasiswa Keperawatan

Awaludin, I. (2015). Tingkat stres akademik pada mahasiswa penerima program beasiswa pengembangan diri (beastudi etos) wilayah Jakarta dan Bogor. Depok: Skripsi Fakultas Ilmu Keperawatan. Universitas Indonesia.

Dew, J., \& Tulane, S. (2015). The association between time spent using entertainment media and marital quality in a contemporary dyadic national sample. Computer Games, 36(4), 621632.

https://dx.doi.org10.1007/s10834 -014-9427-y

Domingo, M. G., Gargante, A. B. (2016). Exploring the use of educational technology in primary education: Teacher's perception of mobile technology learning impacts and applications' use in the classroom. Computers in Human Behavior, 56, 21-28. https://remote-

lib.ui.ac.id:2116/10.1016/j.chb.20 15.11.023

Éilish Duke, Christian Montag, Smartphone addiction, daily interruptions and self-reported productivity, Addictive Behaviors Reports, Volume 6, 2017, Pages 90-95, ISSN 23528532 ,

https://doi.org/10.1016/j.abrep.20 17.07.002.

Gupta, A., Khan, A. M., Rajoura, O. P., \& Srivastava, S. (2018). Internet addiction and its mental health correlates among undergraduate college students of a university in North India. Journal of family medicine and primary care, 7(4), 721-727.

Goff, A. (2011). International Journal of Nursing Learned Resourcefulness in Baccalaureate
Nursing Students Learned Resourcefulness in Baccalaureate Nursing Students, 8(1).

Hegde, A. M., Suman, P., Unais, M., \& Jeyakumar, C. (2019). Effect of electronic gadgets on the behaviour, academic performance and overall health of school going children- A descriptive study. Journal of Advanced Medical and Dental Sciences Research, 7(1), 100-103. doi:http://dx.doi.org/10.21276/ja mdsr

Hussain, Mark D. Griffiths \& Thom Baguley (2012) Online gaming addiction: Classification, prediction and associated risk factors, Addiction Research \& Theory, 20:5, 359-371, DOI: 10.3109/16066359.2011.640442

Kumar, S., Kumar, A., Badiyani, B., Singh, SK., Gupta, A., \& Ismail, MB. (2018). Relationship of internet addiction with depression and academic performance in Indian dental students. Clujul Medical, 91(3):300.

Kumar, Aravind \& Sherkhane, Mayur. (2018). Assessment of gadgets addiction and its impact on health among undergraduates. International Journal Of Community Medicine And Public Health. 5. 3624. 10.18203/23946040.ijcmph20183109.

Labrague, L. J., Mcenroe, D. M., Alexis, J., Santos, A. D. L., \& Edet, O. B. (2018). Nurse Education Today Examining stress perceptions and coping strategies among Saudi nursing students: A systematic review. Nurse Education Today, 65(March), 192-200. https://doi.org/10.1016/j.nedt.201 8.03.012

Labrague, L. J., Stress, P., \& Scale, P. 
Giur Hargiana \& Tia Sintiawati

Hubungan Ketergantungan Gawai dengan Stres Akademik Pada Mahasiswa Keperawatan

R. (2013). Stress, Stressors, and Stress Responses of Student Nurses in a Government Nursing School, 7.r.

Morris, Neli \& Pickens, Jaclyn. (2017). "I'm Not a Gadget": A Grounded Theory on Unplugging. The American Journal of Family Therapy. 45. 1-19.

10.1080/01926187.2017.136566 5.

Nayak, Shalini G. 2019. "Impact of Procrastination and TimeManagement on Academic Stress among Undergraduate Nursing Students: A Cross Sectional Study." International Journal of Caring Sciences 12 (3): 1480-86. http://remotelib.ui.ac.id:2112/login.aspx?dire $\mathrm{ct}=$ true $\& \mathrm{db}=\mathrm{rzh} \& \mathrm{AN}=13954493$ 0\&site=ehost-live.

Papazisis, G., Tsiga, E., Papanikolaou, N., \& Vlasiadis, I. (2008). Psychological distress, anxiety and depression among nursing students in Greece. Vol 1 Issue 1. International Journal of Caring Science, 1(1):42-46.

Psychology Foundation Of Australia. (2010). Depression Anxiety Stress Scale. Http://Www2.Psy.Unsw.Edu.Au/ Group/Dass

Rani S, Singh TK. A Study of Family Burden and Academic Related Stress of GNM Nursing Students. Journal of Psychosocial Research. 2018;13(2):417-424. doi:10.32381/JPR.2018.13.02.16.

Rao, R.B. (2013). Academic Stress Scale.

Http://shodhganga.inflibnet.ac.in/ bitstream/10603/8093/14/14_appe ndices. pdf.

Revathi, K. S., Nair, S., \& Achuthan, A. (2020). Influence of technological gadgets on health and lifestyle of medico. National Journal of Physiology, Pharmacy and Pharmacology, 10(3), 201205.

doi:http://dx.doi.org/10.5455/njpp p.2020.10.12377201908012020

S., Jirel, Sharma B. D., and Dawadi N. 2018. "Academic Stress and SelfEsteem among Nursing Students." Journal of Institute of Medicine 40 (3): 60-64. http://remote-

lib.ui.ac.id:2112/login.aspx?direc $\mathrm{t}=$ true $\& \mathrm{db}=\mathrm{a} 9 \mathrm{~h} \& \mathrm{AN}=137139362$ $\&$ site $=$ ehost-live

Smith, A. (2015). U.S. Smartphone Use in 2015. Retrieved from http://www.pewinternet.org/2015 /04/01/us-smartphone-use-in2015/

Tsatsou, P. (2016). Digital technologies in the research process: Lessons from the digital research community in the UK. Computers in Human Behavior, 61, 597-608

Waghachavare, V. B., Dhumale, G. B., Kadam, Y. R., \& Gore, A. D. (2013). A Study of Stress among Students of Professional Colleges from an Urban area in India, 13(August), 429-436. 